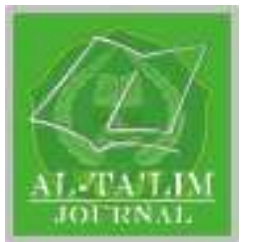

\author{
AL-TA'LIM JOURNAL, 24 (2), 2017, (103-109) \\ (Print ISSN 1410-7546 Online ISSN 2355-7893) \\ Available online at http://journal.tarbiyahiainib.ac.id/index.php/attalim
}

\title{
The Development of E-Learning Media Based Moodle to Increase Science Development and Islamic Studies in STAIN Gajah Putih
}

Received:04 ${ }^{\text {th }}$ April 2017; Revised: 21 $1^{\text {st }}$ April 2017; Accepted: $25^{\text {th }}$ July 2017

Permalink/DOI: http://dx.doi.org/10.15548/jt.v24i2.275

Leni Agustina Daulay*)

Sekolah Tinggi Agama Islam Negeri Gajah Putih Takengon, Aceh

E-mail: agustina_leni@yahoo.com

\section{Firmansyah}

Sekolah Tinggi Agama Islam Negeri Gajah Putih Takengon, Aceh

E-mail: fmanb88@gmail.com

\section{Rahmanita Zakaria}

Sekolah Tinggi Agama Islam Negeri Gajah Putih Takengon, Aceh

E-mail: zrahmanita@gmail.com

*) Corresponding Author

\begin{abstract}
Along with the development of information technology, which more rapidly, the need of a concept and mechanism of Information Technology-based learning becomes inevitable. Then, concept known as e-learning take affect transformation of occurs conventional education into digital form, both the content and the system that is bridged by the technology of internet. The concept of e-learning gives the possibility of interaction between lecturers and students, either the students in the classroom or outside the classroom intensively. This study aimed to obtain e-learning media based Moodle is effective to support the development of science and Islamic studies in Gayo through a series of development process. The finding of the study showed that e-learning based Moodle was conducted by using 4-D model (Four D Model). The results also showed that of development activities are: (1) e-learning media in Gayo which can be seen in www.elearninggayobelajar.com and (2) the use of guide books for lecturers and teachers. The Finding also indicated that the development of Elearning based Moodle is reliable or has a high level of reliability if $\mathrm{t}$ is used in university.
\end{abstract}

Keywords: E-learning, Moodle, science development, Islamic studies

How to Cite: Daulay, L., Firmansyah, F., \& Zakaria, R. (2017). The development of e-learning media based moodle to increase science development and Islamic studies in STAIN Gajah Putih. Al-Ta Lim Journal, 24 (2). doi:http://dx.doi.org/10.15548/jt.v24i2.275

\section{INTRODUCTION}

The information technology that is used in learning in school or in College, namely electronic learning (e-learning) to improve the quality of education (Riswandi, 2017; A. R. Sari, 2006; M. Sari, 2014). Elearning is made to facilitate a lecture/teacher in setting up learning activities and interact with students without limited time and space. During this time, the learning process in the classroom are always applying learningcentered system where students always expect the source of teachers, while students in the case are not very active in the class due to time limitation, it will make the learning activities are not creative because students are nor required to think critically and independently in the learning activities so that need to be considered the applying of learning which engage the students more in the learning process.

E-learning can be implemented because the interest service. Now you can enjoy the convenience of an interest connection for free with the wireless videlity (wifi), it has got to some education institutions such as secondary school and college that can be used by employees, 
students, teachers, and professors to ease the implementation of e-learning.

Today, the development of e-learning system-based opensource has been widely carried out by communities of developers. Opensource is a type of application software that is free download and can be freely used to modified. Some e-learning based opensource taht have a lot of user community and offers a complete system is eFont, Moodle, Dokeos, Ilias and Claroline.

From the results of the survey on application of e-learning to support teaching learning process at educational institutions use quality standard ISO/IEC 9126, produced function aspects of quality value and usability of two system of learning, in example efont and moodle. From the results of measurements of the quality aspects of functionality and usability that was done showed that the system of efont has a value of quality 0.962745 , it is higher than the value of quality moodle registration 0.90925 . the details of the measurement results show that efont is superior in usability and characteristics and moodle has the edge characteristics of the functionality (Barr, Gower, \& Clayton, 2007; Nurseha \& Pradany, 2014; Psycharis, Chalatzoglidis, \& Kalogiannakis, 2013; Silva \& Figueira, 2012; Zoran \& Rozman, 2010).

As moodle stands for Modular ObjectOriented Dynamic Learning Environment which means a place of dynamic learning with the use of object-oriented models (Antonenko, Toy, \& Niederhauser, 2004; Cole \& Foster, 2007). The moodle application first developed by Martin Daougiamas in August 2002 which the moodle version 1.0. Currently, moodle can be used by anyone in opensource. Beside an acronym, Cole and Foster also define moodle as a verb that means the process of doing such an exciting game and leads to addition of insight and creativity.

Moodle can be installed online as well as offline. Sustaining required so that moodle application can run offline is Apache Web
Server, PHP, MySQL or PostgreSQL database. All of them can be obtained by downloading Xampp. Moodle which is installed directly by online need hosting, domain, and file moodle. Contol panel which is no longer offline in the form of xampp control panel but it does through the online control panel, in example by using cPanel.

The advantages of moodle is a light and simple, efficient, and compatible with many browsers, the installation is very easy with the support with a variety of languages, including Indonesian language, availability of site management for overall site settings, the change of module, and so on, the availability of user management (user management) and good management course (Al-Ajlan \& Zedan, 2008; Aydin \& Tirkes, 2010; Beatty \& Ulasewicz, 2006; Kakasevski, Mihajlov, Arsenovski, \& Chungurski, 2008; MartínBlas \& Serrano-Fernández, 2009).

The ease of installation in arranging elearning is one of the researchers' consideration chose moodle e-learning as a base which will be developed.

Moodle has a variety of facilities that could be useful in support of learning activities (Howard, Remenyi, \& Pap, 2006; Monahan, McArdle, \& Bertolotto, 2008; Romero, Ventura, \& García, 2008; Sclater, 2008). Facilities contained on the moodle such as assignment, chat, forum, quiz, and survey. An explanation for each of the facilities according to Yuliastuti, Pujayanto, \& Ekawati (2014) is as follows:

1. Assignment is used to give assignment to students by online. Students can access the material duties and colleting duties by sending the file of their work's results.

2. Chat is used by teachers and students to interact with each other by online in dialogue texts (onlne conversations)

3. The forum is an online discussion forum among teachers and students in discussing topics that relate to learning material.

4. The quiz is used to perform the exam tests online. 
5. The survey used to make the trail of opinions.

Product e-learning based moodle is expected to make students study independently and capable in mastering the development of science and technology continue all at once. In addition, information technology as well as a learning tool. The progress of information technology were able to help creating learning media in various forms. The media can be multimedia devices for simulation, e-book, e-learning and more. In this study, the concept of technology through learning tools is manifested in the form of e-learning moodle.

With the mastery of information technology, are expected to be born students of STAIN Gajah Putih Takengon who are creative and innovative, constructive, dynamic, capable in competing in global era, still rooted in the country's ideological values, the values of the Islamic religion, cultural values of the nation and the relevant customs vulue shades of civilization.

The matter will be examined in this study is how to develop e-learning based moodle students' as learning media to support the development of science and Islamic studies in STAIN Gajah Putih Takengon.

\section{METHOD}

The development of learning model is used to in this study refers to the type of development model 4-D (Four D Model) expressed by Setyosari (2010). The four stages are the stage of definition (define), stage of design (design), stage of development (develop) and the stage of spread (disseminate), these development Models tailored to the needs and context of the research. The stages of development on the model in a nutshell as follows.

1. The definition Phase (define)

The purpose of the definition phase is to eastablish and define the requirements of development.
2. Stage of design (design)

This stage aims to design learning media elearning with guided books for lectures and teachers thus obtained the initial design/prototype.

3. Development stage (develop)

The purpose of the development stage is to produce a draft or final design of elearning and use of the guided book for lectures and teachers. The final design has been through the revision based on the inputs from the experts and data obtained from the tests.

4. Distribution stage (disseminate)

In this phase, researchers perform socialization to introduce product research results to the lectures and students in STAIN Gajah Putih Takengon.

\section{RESULTS AND DISCUSSIONS}

The following described the results obtained on each e-learning development process in accordance with the model development of 4-D.

\section{The Results of The validation on The E- learning Media}

Aspects that are assessed in validating e-learning based moodle is a software engineering aspects and aspects of audio communication. The following summary of the results of the evaluation of validity and reliability e-learning based moodle

Table 1. Summary of the assessment of e-learning based moodle results.

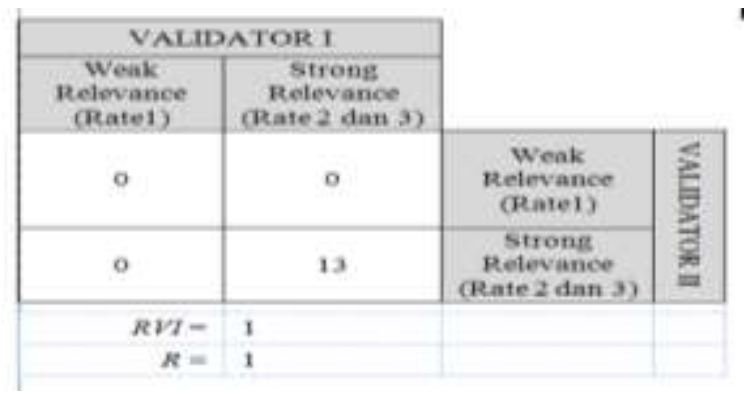

The results of the analysis show that coefficient of the validity for the e-learning based moodle is 1.00, this means interventions undertaken in developing elearning based moodle can be declared valid 
or have a high level of content validity. The results of the analysis also showed that the realiability coefficient obtained for e-learning based moodle based on the results of the assessment of the experts is 1.00 which means reliability or have a high level of reliability.
Although the overall aspects have meet the criteria of validity generally elearning based moodle can be used but the votes need to be little bit of revision. There are some suggestions from the validators to note for perfection of e-learning. Such suggestion as follows:

Table 2. Revision e-learning based moodle on assessment

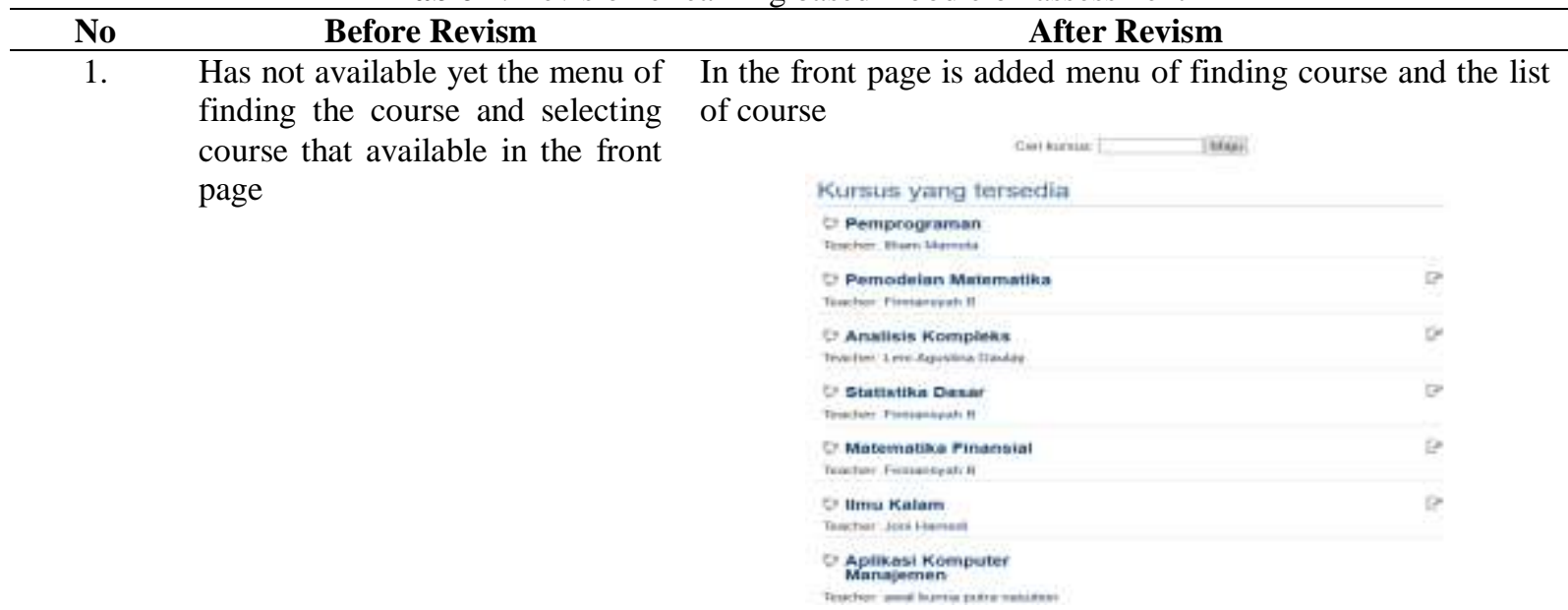

2. When register as the user, user candidate can include the user's name format freely so it can be difficult when administrating the teaching and learning process in e-learning

3. Has not been completed yet the support video
Adding the information about username in NIP/NK or NPM/NIP format

$$
\text { Ini yang pertama kall Anda kesies? }
$$

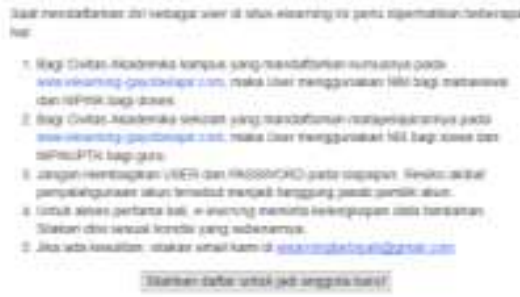

Adding the video tutorial of how to register as a user in front page

Berita Situs

\section{The Results of The Validation Handbook Use of E-learning}

Aspects are assessed in validating elearning based moodle guided book to grasp, systemic aspects, coherently, and logic flow is clear, the clarity of explanation, discussion, and examples, as well as aspects of the format of the presentation space/layout. The following summary of the evaluation of validity and realiability results of e-learning based moodle's guided book. 
Table 3. Summary of the evaluation e-learning based moodle guided book

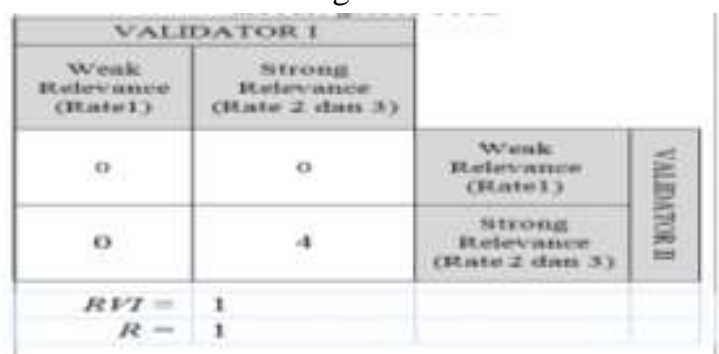

The results of the analysis show that coefficient of the validity for the e-learning based moodle guided book is 1.00 , this means interventions undertaken in developing $\mathrm{e}$ learning based moodle guided book could be declared is valid or have a high level of content validity. The results of the analysis also showed that the realiability coefficient obtained for e-learning based moodle guided book upon the results of the expert assessment is 1.00 which means reliability or have a high level of reliability.

Although the overall aspects have fulfilled the criteria of validity and generally e-learning based moodle guided book can be used but the votes need to be a little bit of revision. There are some suggestions from the validator to note the perfection e-book learning. Such as suggestions as follows:

1. Image on guidebooks, it is better Indonesian language so that the reader understand it more easily (validator).

2. it is better to provide the guided book of usage more e-learning for students (validator).

3. The modul is generally pretty good, because it describes an easy to understand language and layout/design also increases the ease in understanding the contents of modul in the form of elearning usage guide (Validator II).

4. The advice of the validator related to visualization of guide book in the language of Indonesia has not been accommodated by the researchers, this is because lecturer as the users still can follow the visualization in English. In addition each item or theme in settings that use visualization in English always provided explanation in Indonesian language. Other suggestions is to provide guidebooks for students responded by setting up a tutorial video for students to register as a user. As for how to follow the activity in the course is depend on the setting of the course by the lecture.

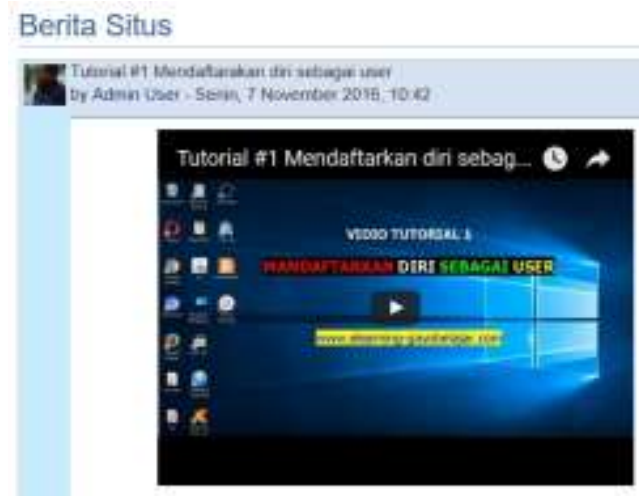

Figure 1. Video Tutorial

\section{CONCLUSION AND RECOMMENDATION}

This research aims to gain learning media e-learning based moodle that is feasible to support the development of science and Islamic studies in STAIN Gajah Putih Takengon through a series of process development. Based on the purpose of the research and the research results that have been outlined, it can be summed up that, first, the results of development activities are in form of learning media e-learning Gayo Belajar and guided book usage for lectures and teachers.

The other results of validation experts/pundits noted that intervention undertaken in developing e-learning based moodle could be declared valid or have a high level of content validity. The results of the analysis also shows the development of elearning based moodle is reliable or have a high level of reliability.

Third, the results of validation experts/pundits found that intervention undertaken in developing the e-learning based moodle guided book could be declared valid or have a high level of content validity. The 
results of the analysis also shows the development of e-learning based moodle guided book is reliable or have a high level of reliability.

\section{REFERENCES}

Al-Ajlan, A., \& Zedan, H. (2008). Why moodle. In Future Trends of Distributed Computing Systems, 2008. FTDCS'08. 12th IEEE International Workshop on (pp. 58-64). IEEE.

Aydin, C. C., \& Tirkes, G. (2010). Open source learning management systems in e-learning and Moodle. In Education Engineering (EDUCON), 2010 IEEE (pp. 593-600). IEEE.

Barr, H., Gower, B., \& Clayton, J. (2007). Faculty response to the implementation of an open source learning management system in three tertiary institutions in New Zealand. Computers in the Schools, 24(3-4), 125-137.

Beatty, B., \& Ulasewicz, C. (2006). Faculty perspectives on moving from Blackboard to the Moodle learning management system. TechTrends, 50(4), 36-45.

Howard, L., Remenyi, Z., \& Pap, G. (2006). Adaptive blended learning environments. In International Conference on Engineering Education (pp. 23-28).

Kakasevski, G., Mihajlov, M., Arsenovski, S., \& Chungurski, S. (2008). Evaluating usability in learning management system Moodle. In Information Technology Interfaces, 2008. ITI 2008. 30th International Conference on (pp. 613-618). IEEE.

Martín-Blas, T., \& Serrano-Fernández, A (2009). The role of new technologies in the learning process: Moodle as a teaching tool in Physics. Computers \& Education, 52(1), 35-44.

Monahan, T., McArdle, G., \& Bertolotto, M. (2008). Virtual reality for collaborative e-learning. Computers \& Education, 50(4), 1339-1353.

Nurseha, Y. D., \& Pradany, L. N. (2014). Survei aplikasi e-learning untuk mendukung proses belajar mengajar pada institusi pendidikan menggunakan standar kualitas ISO/IEC 9126. Ultima Infosys, 5(2), 106-111.

Psycharis, S., Chalatzoglidis, G., \& Kalogiannakis, M. (2013). Moodle as a learning environment in promoting conceptual understanding for secondary school students. Eurasia Journal of Mathematics, Science \& Technology Education, 9(1), 11-21.

Riswandi, R. (2017). The development of a computer based education Management Information System (MIS) Model in Elementary School Bandar Lampung. Al-Ta Lim Journal, 24(1), 9-18.

Romero, C., Ventura, S., \& García, E. (2008). Data mining in course management systems: Moodle case study and tutorial. Computers \& Education, 51(1), 368-384.

Sari, A. R. (2006). Pengembangan software aplikasi komputer berbasis expert system technology dalam pembelajaran akuntansi. Jurnal Pendidikan Akuntansi Indonesia, 5(1).

Sari, M. (2014). The use of facebook in blended course in teacher training college. Al-Ta Lim Journal, 21(2), $145-153$ 
Sclater, N. (2008). Web 2.0, personal learning environments, and the future of learning management systems. Research Bulletin, 13(13), 1-13.

Setyosari, P. (2010). Metode penelitian pendidikan dan pengembangan. Jakarta: Kencana.

Silva, A., \& Figueira, Á. (2012). Visual analysis of online interactions through social network patterns. In Advanced Learning Technologies (ICALT), 2012 IEEE 12th International Conference on (pp. 639-641). IEEE.
Yuliastuti, N., Pujayanto, P., \& Ekawati, E. Y. (2014). Pengembangan media pembelajaran IPA terpadu berbasis elearning dengan moodle untuk siswa Sekolah Menengah Pertama pada tema pengelolaan sampah. Jurnal Pendidikan Fisika, 2(1).

Zoran, A. G., \& Rozman, K. (2010). Students perceptions of using Moodle. In 4th International Conference Proceedings, Koper 21 May 2010. 